\title{
Effect of Antioxidants in Fresh Cut Radishes During the Cold Storage
}

\author{
Juan Saavedra del Aguila ${ }^{1 *}$, Fabiana Fumi Sasaki ${ }^{2}$, Lília Sichmann Heiffig ${ }^{3}$, Edwin Moisés \\ Marcos Ortega $^{4}$, Marcos José Trevisan ${ }^{1}$ and Ricardo Alfredo Kluge ${ }^{2}$ \\ ${ }^{I}$ Departamento de Produção Vegetal; Escola Superior de Agricultura "Luiz de Queiroz"; Universidade de São \\ Paulo; C.P.: 9; jsaguila@esalq.usp.br; 3418-900; Piracicaba - SP - Brasil. ${ }^{2}$ Departamento de Ciências Biológicas; \\ Escola Superior de Agricultura "Luiz de Queiroz"; Universidade de São Paulo; C.P.: 9, 13418-900; Piracicaba - \\ SP - Brasil. ${ }^{3}$ Instituto Agronômico; Central de Grãos e Fibras; C.P.: 28; 13075-630; Campinas - SP - Brasil. \\ ${ }^{4}$ Departamento de Ciência Básica; Escola Superior de Agricultura "Luiz de Queiroz"; Universidade de São Paulo; \\ C.P.: 9; 13418-900; Piracicaba-SP-Brasil.
}

\begin{abstract}
The objective of this study was to evaluate the efficiency of antioxidants in the cold storage of fresh cut radishes. The shredded roots were submerged in the respective treatments during 3 min (ascorbic acid or citric acid) and stored at $5^{\circ} \mathrm{C}$ and $90 \% \mathrm{RH}$ during 10 days. The radish treated with ascorbic acid showed the higher respiratory rate in the first $4 \mathrm{~h}$ after the processing during the storage. The content of total soluble solids (TSS) was significantly higher in the treatment with citric acid. There was an increase in the content of ascorbic acid after two day of storage in the treatments with this antioxidant. The values of lightness $\left(L^{*}\right)$ were decreasing along the storage. Citric acid treatments caused strongly red coloration in the minimally processed roots. None of the treatments avoided the browning of the shredded radishes during the cold storage.
\end{abstract}

Keywords: Raphanus sativus L., enzymatic browning, respiration, fresh-cut, postharvest

\section{INTRODUCTION}

Minimally processed vegetables constitute a food segment that has gradually and increasingly attracted the consumers. When buying such products, they have the opportunity to acquire fresh-like food products, with quality assurance, since the nutritional, sanitary and sensory aspects, as well as good producing procedures, are preserved (Willey, 1997; Scalon et al., 2000; Vitti et al., 2005; Del Aguila et al., 2006).

Since the vegetables are living organisms, the greater the processing level, the higher the impact on the minimally processed product. Such impact accelerates the deterioration and shortens the product's shelf life. Injuries caused by cuts the quickly stimulate the respiratory activity and ethylene production, inducing the biosynthesis of enzymes associated with several biochemical reactions responsible for changes in color, aroma, texture and nutritional value, leading to senescence (Cantwell, 1992; Artes et al., 1998). Moreover, defense compounds against the stresses may be produced by the tissues, which can endanger the product quality (Brecht, 1995).

Browning is one of the main causes of quality loss in minimally processed products, among other undesirable changes that processing procedures

\footnotetext{
* Author for correspondence
} 
may cause (Cantwell, 1992; Brecht, 1995; Cantwell, 1996; Artes et al., 1998). Therefore, controlling the physiological response to injuries in the preparation process is the key factor to obtain a good quality minimally processed product.

Enzymatic browning basically consists of phenolic substrates oxidation and subsequent nonenzymatic polymerization of $o$-quinones, very reactive molecules that condense quickly, combining with amino or sulphidric groups of proteins and reducing sugars, forming brown pigments of high molecular weight and unknown structure, called melanin (Araújo, 1995). The browning process is unleashed when cutting is carried out during the vegetable processing, when phenolic substrates located in the vacuoles get in contact with the catalyzing enzymes from polyphenol oxidation reactions, generally occurring in the cytoplasm and being associated with the membrane structures of plasmids. The enzymatic browning happens when the phenolic substrates, oxidative enzymes and oxygen react under ideal $\mathrm{pH}$ (6 to 8 ), temperature and water activity conditions. The main enzyme responsible for browning reactions is the polyphenoloxidase (PPO), although other enzymes, such as peroxidase, may also be responsible for this process (Artes et al., 1998).

Antioxidant or reducing agents prevent browning through reducing enzymatically formed $o$ quinones into the respective colorless diphenols. They may also react irreversibly with the $o$ quinones, forming more stable colorless compounds, such as ascorbic acid and its derivatives. The beneficial effect of the ascorbic acid is attributed to several aspects, such as capturing of oxygen and protection, forming a barrier that prevents oxygen diffusion toward the product, thus, reducing the production of $o$ quinones and inhibiting the PPO (Artes et al., 1998).

Citric acid may also be used as an antioxidant and chelating agent, acting synergistically with the ascorbic or the erythorbic acid and their neuter salts to chelate peroxidants, which may cause rancidity and inactivate enzymes such as the PPO (Wiley, 1994). The content of ascorbic acid of most vegetables decreases when bruising, trimming and cutting occurs (Lee and Kader, 2000).

Although being a crop of minor importance regarding the cultivated area, radish (Raphanus sativus L.) is considered important for many small property owners who grow a great variety of vegetables. Radish can be used as a cash crop between others of longer cycles and more defined sowing time due to its relative rusticity and short cycle of around 30 days. In addition, it is an excellent source of calcium, phosphorus and manganese, contains vitamins $B_{1}$ and $B_{2}$, nicotinic acid and vitamin $\mathrm{C}$, acts as a diuretic and antiscorbutic agent, and stimulates the digestive glandules and liver - promoting better digestion by the increase of bile production (Minami and Netto, 1994). Besides, radish is gaining a great market share of minimally processed products, although its physiologic behavior after packaging is still little known.

The purpose of this work was to test two wellknown antioxidants and their combinations on the minimization of enzymatic browning in radish roots due to minimal processing.

\section{MATERIAL AND METHODS}

Leaves and roots of radish, "Giant Crimson" cultivar, harvested in the Piracicaba-SP region, were taken to the Post-Harvest Laboratory of the Vegetable Production Department at "Escola Superior de Agricultura "Luiz de Queiroz" USP", where they were selected for firmness, absence of mechanical injuries and visible infections.

The initial stages of minimal processing were carried out at $15^{\circ} \mathrm{C}$, with the use of appropriate personal protection equipment, such as gloves, caps, masks, aprons and boots. With the use of a sharp knife, the radish roots were separated from the leaves and those presenting undesirable processing problems were discarded. Then, the selected roots were washed under running water to remove organic matter and other impurities from the product. Disinfection by submerging the roots in water containing $200 \mathrm{mg} \mathrm{L}^{-1}$ active chlorine for 10 minutes was carried out to reduce the initial microbial content over the product. The sanitizing agent used was Dichlorine-S-dihydrate Sodic Triazinatriona $\left(\right.$ SUMAVEG $^{\circledR}$, Diversey LeverIndustries Gessy Lever Ltd). The excess of water was drained with the aid of a sieve. The material was taken to a cold chamber $\left(10^{\circ} \mathrm{C}\right)$, where the other stages of the minimal processing were conducted. 
The roots selected for minimal processing were cut in an industrial processing unit (Robot Coupe $\AA$, CL50 version D) to $2 \mathrm{~mm}$-thick shreds. Next, the material was placed in nylon bags and submerged in distilled water at $5^{\circ} \mathrm{C}$ for cooling and removing the cell juice resulting from cuts.

The minimally processed radish roots were submerged in distilled water containing $200 \mathrm{mg} \mathrm{L}^{-}$ ${ }^{1}$ active chlorine for 3 minutes in order to reduce the remaining microbial content. After sanitization, the radish roots were submerged in distilled water with $3 \mathrm{mg} \mathrm{L}^{-1}$ active chlorine for 1 minute and the excess of chlorine was removed.

After rinsing, the product was submitted to the following treatments for three minutes: control (immersion in distilled water); immersion in citric acid solution at $2000 \mathrm{mg} \mathrm{L}^{-1}$ concentration; immersion in ascorbic acid solution at $2000 \mathrm{mg} \mathrm{L}^{-1}$ concentration; and immersion in citric acid solution $\left(1000 \mathrm{mg} \mathrm{L}^{-1}\right)+$ ascorbic acid $(1000 \mathrm{mg}$ $\mathrm{L}^{-1}$ ), resulting in a total concentration of $2000 \mathrm{mg}$ $\mathrm{L}^{-1}$. After the conduction of treatments, the minimally processed radish roots were placed in a centrifuge for 1 minute (average of $800 \mathrm{x} \mathrm{g}$ ), eliminating the excess water from the product.

Subsequent to the preparation procedures and the conduction of treatments, the product was placed in expanded polystyrene trays wrapped into $14 \mu \mathrm{m}$ thick polyvinyl chloride (PVC) film, and stored at $5^{\circ} \mathrm{C}\left( \pm 1^{\circ} \mathrm{C}\right)$ and $90 \%( \pm 5 \%)$ RH for 10 days. Physical-chemical analyses were carried out every 2 days, while the respiratory rate was evaluated daily.

To measure the respiratory rate, $130 \mathrm{~g}$ of the product were placed into $580-\mathrm{mL}$ hermetic containers. A rubber septum was placed on each pot lid, through which a gas sample was taken. A sample from each pot was collected with the aid of a 1-mL syringe and then was analyzed with a gas chromatographer (Thermoffinigan, model Trace 2000 GC). The respiratory rate was determined within $5 \mathrm{~h}$ after minimal processing, by means of 4 readings, the first of which (time zero) was carried out $1 \mathrm{~h}$ after processing. Posterior readings were conducted daily for 10 days. Results were expressed in $\mathrm{mg} \mathrm{CO}_{2} \mathrm{~kg}^{-1} \mathrm{~h}^{-1}$.

The total soluble solids (TSS) was determined by direct reading of centrifuged fresh cut in a digital refractometer with results expressed in percentage $(\%)$. Titratable acidity (TA) was determined from $10 \mathrm{~g}$ of puree diluted with $90 \mathrm{ml}$ of water, titrated with $0.1 \mathrm{~N} \mathrm{NaOH}$ to $\mathrm{pH} 8.1$ and expressed percentage of malic acid (Carvalho et al., 1990), once this acid represents approximately $80 \%$ of the total organic acids presents in radish (Wang, 1998). Ascorbic acid content was determined by titration (Carvalho et al., 1990) and results expressed in $\mathrm{mg}$ of ascorbic acid per $100 \mathrm{~g}$ of sample. The fresh matter loss was determined as being the difference between the initial and the final mass of each repetition and results were expressed in \% of fresh matter loss. Lightness $\left(\mathrm{L}^{*}\right), \mathrm{a}^{*}$ and $\mathrm{b}^{*}$ values, was determined using a colorimeter (Minolta). Readings were conducted directly on the minimally processed product.

The experimental design adopted was the completely randomized $4 \times 6$ factorial scheme. The factors studied were treatments (4 levels) and storage time (6 levels). Four trays with $130 \mathrm{~g}$ of minimally processed product were used for each treatment. Results were submitted to variance analysis ( $F$ test $)$ and, where significant, means were compared using the Tukey test at $P \leq 0.05$ (SAS Institute, Inc., 1998).

Six replicates per treatment were used to quantify the respiratory rate. Results were submitted to analysis of repeated measurements, which differed from the ordinary variance analyses, once a significant correlation for storage time was obtained. Since the same experimental unit was employed for the whole experiment, this correlation was evaluated by Sphericity Test. The comparison of means for treatments was carried out by univaried analysis (for each day separately) and Tukey test at $P \leq 0.05$.

\section{RESULTS AND DISCUSSION}

Minimally processed radish treated with ascorbic acid showed the highest respiratory rate during the first $4 \mathrm{~h}$ of evaluation, followed by radish treated with ascorbic + citric acids, control and citric acid, which showed the lowest respiratory rate (Fig. 1). Four hours after processing, the respiratory rates were $15.27 \mathrm{mg} \mathrm{CO} \mathrm{kg}^{-1} \mathrm{~h}^{-1}$ for treatment with ascorbic acid, $12.19 \mathrm{mg} \mathrm{CO}_{2} \mathrm{~kg}^{-1} \mathrm{~h}^{-1}$ for treatment with ascorbic + citric acids, $10.02 \mathrm{mg} \mathrm{CO}_{2} \mathrm{~kg}^{-1} \mathrm{~h}^{-1}$ for control and $5.52 \mathrm{mg} \mathrm{CO}_{2} \mathrm{~kg}^{-1} \mathrm{~h}^{-1}$ for treatment with citric acid.

The respiratory rate increased for all the treatments during cold storage, except for the citric acid (Fig. 2). Vitti (2003) also observed that the use of citric acid at different concentrations reduced the 
respiratory rate in minimally processed beet root. Citric acid is one of the controlling agents of the cell respiratory metabolism. According to Taiz and Zeiger (2004), the accumulation of citric acid inhibits the cytosolic pyruvate kinase action, increasing the concentration of phosphoenolpyruvate in the cytosol, which reduces the conversion of fructose $6-$ phosphate in fructose 1.6 - biophosphate, thus reducing glycolysis. Citric acid also reduces the cytosolic $\mathrm{pH}$ and may directly influence the activity of phosphofructokinase (Kato-Noguchi and Watada, 1997).

On the other hand, the treatment with ascorbic acid induced a greater respiratory rate, not only during the first four hours after processing (Fig. 1), but also during the cold storage (Fig. 2). Antoniolli (2004) also observed a greater respiratory rate in minimally processed pineapple treated with ascorbic acid when compared to untreated ones. The increase in respiratory rate observed with the use of ascorbic acid has not been very well explained yet. It could be due to a dysfunction in the vegetal tissue or to its use as a respiratory substrate, considering that, besides soluble carbohydrates, the organic acids, lipids and proteins could also be oxidized for energy production during aerobic respiration (Taiz and Zeiger, 2004).

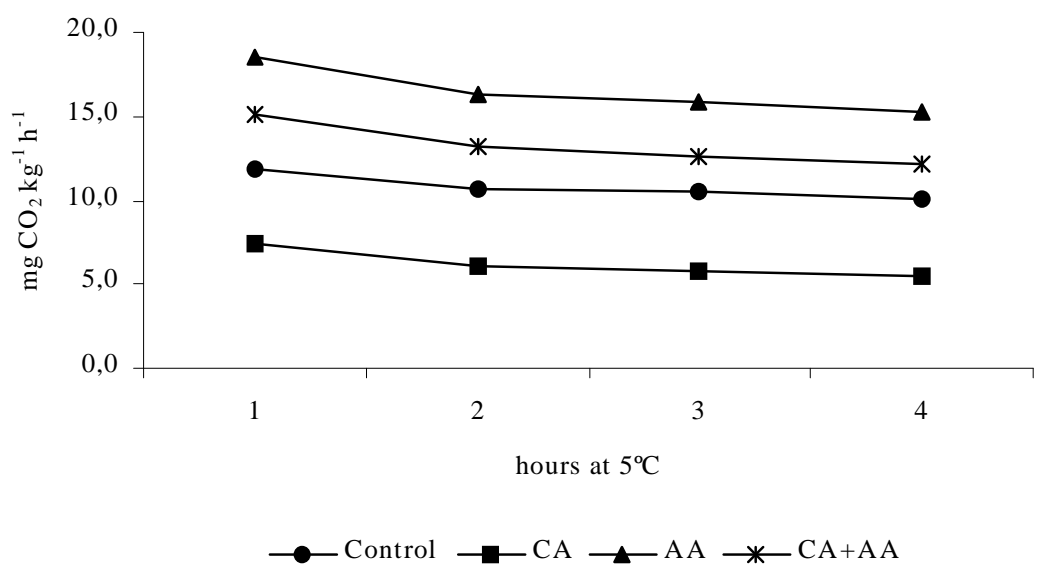

Figure 1 - Respiratory rate $\left(\mathrm{mg} \mathrm{CO}_{2} \mathrm{~kg}^{-1} \mathrm{~h}^{-1}\right)$ of fresh-cut radish with different antioxidant; $\mathrm{CA}=$ citric acid, AA = ascorbic acid.

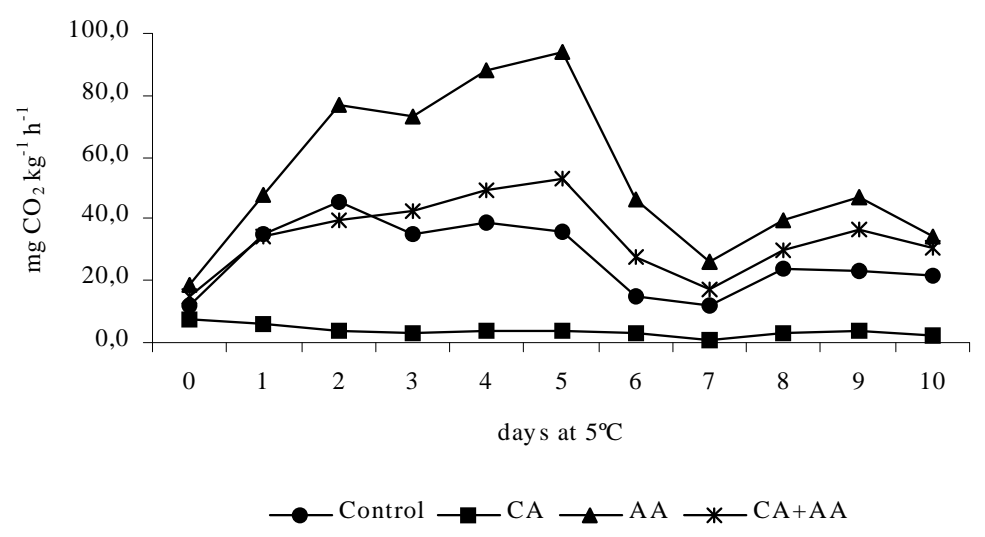

Figure 2 - Respiratory rate $\left(\mathrm{mg} \mathrm{CO}_{2} \mathrm{~kg}^{-1} \mathrm{~h}^{-1}\right)$ of fresh-cut radishes with different antioxidant; $\mathrm{CA}=$ citric acid, $\mathrm{AA}=$ ascorbic acid. 

Two days after the storage, there was a decrease in the TSS amount, which stabilized at the end of the storage period (Table 1). TSS amounts were always lower in the control when compared to the treatments, suggesting a possible highest consumption of carbohydrates during respiration.

Table 1 - Total soluble solids (\%), titratable acidity (\% malic acid) and ascorbic acid on fresh-cut radishes with different antioxidant.

\begin{tabular}{|c|c|c|c|c|c|c|}
\hline \multirow{2}{*}{ Treatments } & \multicolumn{6}{|c|}{ Days at $5^{\circ} \mathrm{C}$} \\
\hline & $\mathbf{0}$ & 2 & 4 & 6 & 8 & 10 \\
\hline & \multicolumn{6}{|c|}{$\%$ TSS.. } \\
\hline Control & $3,50 \mathrm{aA}$ & $2,02 \mathrm{bB}$ & $1,85 \mathrm{cC}$ & 1,72 bCD & $1,62 \mathrm{cD}$ & $1,47 \mathrm{cE}$ \\
\hline $\mathrm{CA}$ & $3,50 \mathrm{aA}$ & $2,42 \mathrm{aBC}$ & $2,62 \mathrm{aB}$ & $2,32 \mathrm{aC}$ & $2,37 \mathrm{aC}$ & $2,27 \mathrm{aC}$ \\
\hline AA & $3,50 \mathrm{aA}$ & $2,47 \mathrm{aB}$ & $2,32 \mathrm{bBC}$ & $2,20 \mathrm{aC}$ & $2,10 \mathrm{bCD}$ & 1,95 bD \\
\hline $\mathrm{CA}+\mathrm{AA}$ & $3,50 \mathrm{aA}$ & $2,32 \mathrm{aBC}$ & $2,45 \mathrm{abB}$ & $2,20 \mathrm{aCD}$ & $2,02 \mathrm{bE}$ & $2,10 \mathrm{abDE}$ \\
\hline $\begin{array}{l}\text { Control } \\
\text { CA }\end{array}$ & $\begin{array}{l}0,05 \mathrm{aA} \\
0,05 \mathrm{aB}\end{array}$ & $\begin{array}{l}0,03 \mathrm{~dB} \\
0,31 \mathrm{aA}\end{array}$ & $\begin{array}{c}0,03 \mathrm{cB} \\
0,29 \mathrm{aA}\end{array}$ & $\begin{array}{c}\ldots \ldots \ldots \ldots \\
0,04 \mathrm{cB} \\
0,27 \mathrm{aA}\end{array}$ & $\begin{array}{l}0,03 \mathrm{bB} \\
0,30 \mathrm{aA}\end{array}$ & $\begin{array}{c}0,03 \mathrm{aB} \\
0,16 \mathrm{aAB}\end{array}$ \\
\hline $\mathrm{AA}$ & $0,05 \mathrm{aB}$ & $0,09 \mathrm{cA}$ & $0,05 \mathrm{cB}$ & $0,05 \mathrm{cB}$ & $0,04 \mathrm{bB}$ & $0,05 \mathrm{aB}$ \\
\hline \multirow[t]{2}{*}{$\mathrm{CA}+\mathrm{AA}$} & $0,05 \mathrm{aD}$ & $0,18 \mathrm{bA}$ & $0,10 \mathrm{bB}$ & $0,08 \mathrm{bBC}$ & $0,05 \mathrm{bD}$ & $0,06 \mathrm{aCD}$ \\
\hline & \multicolumn{6}{|c|}{ 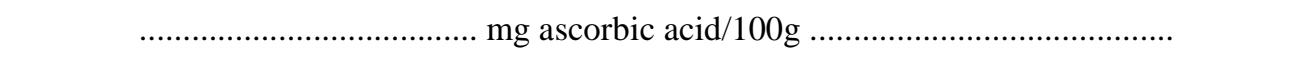 } \\
\hline Control & $19,89 \mathrm{aA}$ & $11,41 \mathrm{cBC}$ & $13,02 \mathrm{bB}$ & $11,72 \mathrm{bBC}$ & $11,21 \mathrm{cBC}$ & $7,45 \mathrm{cC}$ \\
\hline $\mathrm{CA}$ & $19,89 \mathrm{aA}$ & $11,83 \mathrm{cB}$ & 7,24 bC & $6,75 \mathrm{bC}$ & $5,48 \mathrm{dC}$ & $5,35 \mathrm{cC}$ \\
\hline $\mathrm{AA}$ & $19,89 \mathrm{aB}$ & $371,64 \mathrm{aA}$ & $74,15 \mathrm{aB}$ & $40,06 \mathrm{aB}$ & $52,63 \mathrm{aB}$ & $58,02 \mathrm{aB}$ \\
\hline $\mathrm{CA}+\mathrm{AA}$ & $19,89 \mathrm{aC}$ & 179,17 bA & $73,04 \mathrm{aB}$ & $41,96 \mathrm{aC}$ & $18,48 \mathrm{bC}$ & $20,62 \mathrm{bC}$ \\
\hline
\end{tabular}

Mean separation by small letter in column and capital letter in row by Tukey test at $\mathrm{P} \leq 0.05$. CA $=$ citric acid; AA $=$ ascorbic acid.

There were no differences among the treatments as to fresh matter loss, as the maximum loss was only $1 \%$ at the end of the experimental period (data not presented). In fact, no differences were expected for this variable, considering that the treatments carried out did not offer any barrier against the water loss.

As for the acidity evaluation, $0.05 \%$ malic acid was initially observed, while on the $10^{\text {th }}$ day, the observed values were $0.16,0.06,0.05$ and $0.03 \%$ of malic acid for citric acid, citric + ascorbic acids, ascorbic acid treatments and control, respectively (Table 1). Treating the radish with the acids increased the titratable acidity, since all the acids were quantified in this determination. This was clearly observed in the treatments using citric acid until the $8^{\text {th }}$ day of experiment, while for the treatment using ascorbic acid, this increase only happened until the $2^{\text {nd }}$ day of storage, probably due to the quicker acid consumption in antioxidative reactions during the following days.

On the $2^{\text {nd }}$ day of the storage, there was a statistically significant increase in the ascorbic acid amounts in roots submitted to the treatments with ascorbic acid and ascorbic + citric acids, when compared to the observed for the citric acid treatment and control. This pattern remained throughout the storage period (Table 1). On the $10^{\text {th }}$ day, $58.02,20.62,5.35$ and $7.45 \mathrm{mg}$ ascorbic $\mathrm{acid} / 100 \mathrm{~g}$ were obtained for the ascorbic acid, ascorbic + citric acids, citric acid treatments and control, respectively. Increments in the ascorbic acid amount were also observed shortly after the treatments in experiments with minimally processed pineapple (Antoniolli, 2004), kiwifruit (Carvalho and Lima, 2002) and papaya (Miranda, 2001).

Lightness $\left(\mathrm{L}^{*}\right)$ generally decreased after the $2^{\text {nd }}$ day of storage, progressing from an initial value of 74.5 to around 50 to 56 on the $10^{\text {th }}$ day, with no significant differences being observed among the treatments (Table 2). This showed that the antioxidant treatments were not effective in reducing the enzymatic browning in the minimally processed product. 
Table 2 - Lightness $\left(\mathrm{L}^{*}\right)$, color $\left(\mathrm{a}^{*}\right)$, color index $(\mathrm{CI})$ and color $\left(\mathrm{b}^{*}\right)$ on fresh-cut radishes with different antioxidant.

\begin{tabular}{|c|c|c|c|c|c|c|}
\hline \multirow{2}{*}{ Treatments } & \multicolumn{6}{|c|}{ Days at $5^{\circ} \mathrm{C}$} \\
\hline & $\mathbf{0}$ & 2 & 4 & 6 & 8 & 10 \\
\hline \multicolumn{7}{|c|}{ 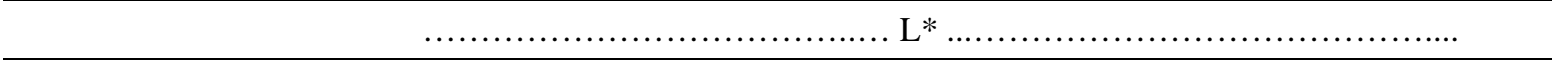 } \\
\hline Control & $74,54 \mathrm{aA}$ & $55,83 \mathrm{aB}$ & $56,12 \mathrm{aB}$ & $53,49 \mathrm{aBC}$ & $56,22 \mathrm{aB}$ & $51,57 \mathrm{aC}$ \\
\hline CA & $74,54 \mathrm{aA}$ & $51,97 \mathrm{bB}$ & $52,02 \mathrm{bB}$ & $53,65 \mathrm{aB}$ & $50,75 \mathrm{bB}$ & $51,67 \mathrm{aB}$ \\
\hline AA & $74,54 \mathrm{aA}$ & $55,10 \mathrm{abB}$ & $55,06 \mathrm{aB}$ & $54,66 \mathrm{aBC}$ & $55,93 \mathrm{aB}$ & $52,41 \mathrm{aC}$ \\
\hline $\mathrm{CA}+\mathrm{AA}$ & $74,54 \mathrm{aA}$ & $52,35 \mathrm{bB}$ & $55,00 \mathrm{abB}$ & $55,22 \mathrm{aB}$ & $54,34 \mathrm{aB}$ & $55,08 \mathrm{aB}$ \\
\hline & & & $a^{*}+\ldots . . .$. & & $453 \mathrm{hH}$ & \\
\hline Control & $-0,55 \mathrm{aB}$ & $3,47 \mathrm{cA}$ & $3,39 \mathrm{cA}$ & $3,54 \mathrm{cA}$ & $4,53 \mathrm{bA}$ & $3,25 \mathrm{aA}$ \\
\hline $\mathrm{CA}$ & $-0,55 \mathrm{aB}$ & $19,13 \mathrm{aA}$ & $22,85 \mathrm{aA}$ & $16,86 \mathrm{aA}$ & $23,95 \mathrm{aA}$ & $13,28 \mathrm{aA}$ \\
\hline AA & $-0,55 \mathrm{aC}$ & $6,94 \mathrm{cA}$ & $3,98 \mathrm{cB}$ & $3,63 \mathrm{cB}$ & 4,19 bB & $4,35 \mathrm{aB}$ \\
\hline $\mathrm{CA}+\mathrm{AA}$ & $-0,55 \mathrm{aD}$ & $13,97 \mathrm{bA}$ & $10,70 \mathrm{bAB}$ & $7,67 \mathrm{bBC}$ & $7,81 \mathrm{bBC}$ & $4,55 \mathrm{aC}$ \\
\hline Control & $-1,89$ & 13,31 & $\begin{array}{c}\text { CI } \ldots \ldots \ldots . . . \\
11,82\end{array}$ & 10,71 & $\begin{array}{l}\cdots \ldots . . \\
10,55\end{array}$ & 7,19 \\
\hline $\mathrm{CA}$ & $-1,89$ & 47,93 & 47,28 & 50,93 & 46,27 & 35,21 \\
\hline $\mathrm{AA}$ & $-1,89$ & 46,14 & 23,86 & 10,98 & 9,12 & 10,94 \\
\hline $\mathrm{CA}+\mathrm{AA}$ & $-1,89$ & 56,54 & 71,79 & 45,69 & 30,64 & 21,07 \\
\hline Control & $3,90 \mathrm{aD}$ & $4,67 \mathrm{bCD}$ & $5,11 \mathrm{bCD}$ & $6,18 \mathrm{aBC}$ & 7,64 bAB & $8,76 \mathrm{aA}$ \\
\hline $\mathrm{CA}$ & $3,90 \mathrm{aA}$ & $7,68 \mathrm{aA}$ & $9,29 \mathrm{aA}$ & $6,17 \mathrm{aA}$ & $10,20 \mathrm{aA}$ & $7,30 \mathrm{aA}$ \\
\hline AA & $3,90 \mathrm{aC}$ & $2,73 \mathrm{bC}$ & $3,03 \mathrm{bcC}$ & $6,05 \mathrm{aB}$ & $8,21 \mathrm{abA}$ & 7,59 aA \\
\hline $\mathrm{CA}+\mathrm{AA}$ & $3,90 \mathrm{aA}$ & $4,72 \mathrm{bA}$ & $2,71 \mathrm{cA}$ & $3,04 \mathrm{bA}$ & $4,69 \mathrm{bA}$ & $3,92 \mathrm{aA}$ \\
\hline
\end{tabular}

Mean separation by small letter in column and capital letter in row by Tukey test at $\mathrm{P} \leq 0.05 . \mathrm{CA}=$ citric acid; $\mathrm{AA}=$ ascorbic acid.

Initial $\mathrm{a}^{*}$ of -0.55 reached $22.85,10.70,3.98$ and 3.39 on the $4^{\text {th }}$ day of storage for the citric acid, ascorbic + citric acids, and ascorbic acid treatments and control, respectively (Table 2). The citric acid treatment was significantly better to the others. On the $10^{\text {th }}$ day of storage, the values were $13.28,4.55,4.35$ and 3.25 for the citric acid, ascorbic + citric acids, and ascorbic acid treatments and control, respectively, with no significant differences among them. No significant differences were observed for $b^{*}$ values among the treatments on the $10^{\text {th }}$ day of storage (Table 2).

Treatments using citric acid altered the color of minimally processed radish, which showed a redish color. This result was demonstrated by using the Mazzuz's equation (1996) for calculating the color index (CI). The Mazzuz's equation is CI $=1000 \times \mathrm{a}^{*} / \mathrm{L}^{*} \mathrm{x} \mathrm{b}^{*}$, with more positive values denoting more intense reddish color (Table 2). Citric acid, despite being a natural antioxidant and promoting a decrease in the respiratory rate of radish, alters the normal color of minimally processed radish roots, conferring them a reddish color, which is commercially undesirable. Until now, the cause of such effect has not been determined, but it may be the result of some biochemical reaction between the citric acid and some other compound found in radish.

In conclusion, none of the treatments avoided the browning of the shredded radishes cold stored at $5^{\circ} \mathrm{C}$ and $90 \% \mathrm{RH}$ during 10 days. Further studies aiming at reducing the browning in minimally processed radish are necessary to increase its shelf life.

\section{RESUMO}

O presente experimento objetivou testar o uso de antioxidantes na conservação de rabanetes minimamente processados. Os rabanetes 
minimamente processados foram submersos nos tratamentos por 3 minutos (ácido ascórbico ou ácido cítrico) e armazenados a $5^{\circ} \mathrm{C}\left( \pm 1^{\circ} \mathrm{C}\right)$ e $90 \%$ $( \pm 5 \%)$ UR durante 10 dias. $\mathrm{O}$ tratamento com ácido ascórbico gerou a maior taxa respiratória nas 4 primeiras horas após o processamento e durante o armazenamento. $\mathrm{O}$ teor de sólidos solúveis totais (SST) foi significativamente maior no tratamento com ácido cítrico. Quanto ao teor de ácido ascórbico, para os tratamentos com ácido ascórbico houve um aumento significativo no $2^{\circ}$ dia. Os valores de luminosidade $\left(\mathrm{L}^{*}\right)$ apresentaram redução durante o armazenamento. Os tratamentos com ácido cítrico provocaram uma forte coloração vermelha nas raízes minimamente processadas. Nenhum dos tratamentos evitou o escurecimento das raízes de rabanete minimamente processadas.

\section{REFERENCES}

Antoniolli, L.R. (2004), Processamento mínimo de abacaxi "pérola". Campinas. Tese (Doutorado) Faculdade de Engenharia Agrícola, Universidade Estadual de Campinas.

Araujo, A. (1995), Escurecimento enzimático em alimentos. Imprensa Universitária, Viçosa.

Artes, F.; Castaner, M.; Gil, M.I. (1998), El pardeamiento enzimático en frutas y hortalizas minimamente procesadas. Food Science Research International, 4, 377-389.

Brecht, J.K. (1995), Physiology of ligthy processed fruits and vegetables. Hortscience, 30, 18-22.

Cantwell, M. (1992), Postharvest handling systems: minimally processed fruits and vegetables. In: Kader, A.A. (Ed.). Postharvest technology of horticutural crops. University of California, Oakland. 277-281.

Cantwell, M. (1996), Fresh-cut products. Maintaining quality and safety. Univ. of California, California.

Carvalho, C.R.L.; Mantovani, D.M.B.; Carvalho, P.R.N.; Moraes, R.M.N. (1990), Análises químicas de alimentos, Campinas.

Carvalho, A.V.; Lima, L.C.O. (2002), Qualidade de kiwis minimamente processados e submetidos a tratamento com ácido ascórbico, ácido cítrico e cloreto de cálcio. Pesquisa Agropecuária Brasileira, 37, 679-685.

Del Aguila, J.S.; Sasaki, F.F.; Heiffig, L.S.; Ortega, E.M.M.; Jacomino, A.P.; Kluge, R.A. (2006), Freshcut radish using different cut types and storage temperatures. Postharvest Biology and Technology, 40, 149-154.

Kato-Noguchi, H.; Watada, A.E. (1997), Citric acid reduces the respiration of fresh-cut carrots. HortScience, 32, 136.

Kays, S.J. (1991), Postharvest physiology of perishable plant products. Van Nostrand Reinhold, New York.

Lee, S.K., Kader, A.A. (2000), Preharvest and postharvest factors influencing vitamin $\mathrm{C}$ content of horticultural crops. Postharvest Biology and Technology, 20, 207-220.

Mazzus, C.F. (1996), Calidad de frutos cítricos: manual para su gestión desde la recolección hasta la expedición. Ediciones de Horticultura, Barcelona.

Minami, K; Netto, J.T. (1994), Cultura do rabanete. ESALQ - Departamento de Horticultura, Piracicaba.

Miranda, R.B. (2001), Avaliação da qualidade do mamão (Carica papaya L.) minimamente processado. Dissertação (Mestrado) - Universidade Federal de Lavras, Lavras.

Sas Institute, INC. (1998), The SAS System for Windows - Release 8,02. Cary,NC.

Scalon, S.P.Q.; Scalon F., H.; Sandre, T.A.; Silva, E.F.; Krewer, E.C.D. (2000), Quality evaluation and sugar beet postharvest conservation under modified atmosphere. Brazilian Archives of Biology and Technology, 43, 181-184.

Taiz, L.; Zeiger, E. (2004), Fisiologia Vegetal. Artmed, Porto Alegre.

Vitti D., M.C. (2003), Aspectos fisiológicos, bioquímicos e microbiológicos em beterrabas minimamente processadas. Dissertação (Mestrado) Escola Superior de Agricultura "Luiz de Queiroz", Universidade de São Paulo, Piracicaba.

Vitti D., M.C.; Yamamoto, L.K.; Sasaki, F.F.; Del Aguila, J.S.; Kluge, R.A.; Jacomino, A.P. (2005), Quality of minimally processed beet roots stored in different temperatures. Brazilian Archives of Biology and Technology, 48, 503-510.

Wang, C.Y. (1998), Methyl jasmonate inhibits postharvest sprouting and improves storage quality of radishes. Postharvest Biology and Technology, 14, 179-183.

Wiley, R.C. (1994), Minimally processed refrigerated fruits and vegetables. Chapman and Hall, New York.

Willey, R.C. (1997), Frutas y hortalizas minimamente processadas y refrigeradas. Acribia, Zaragoza.

Received: March 12, 2006; Revised: November 18, 2007; Accepted: June 25, 2008. 


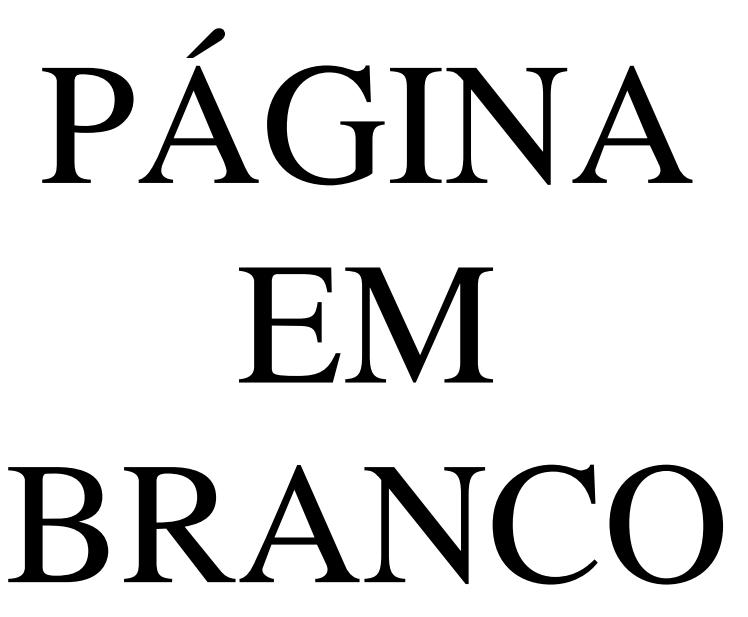

